\title{
Critical Thinking an Antidote to Artificial Intelligence Threat: An Innovation in Teacher Education Practices
}

\author{
Komolafe Blessing Funmi ${ }^{1,2}$ and Qian Xusheng ${ }^{1 *}$ \\ ${ }^{l}$ Curriculum \& Pedagogy Department, Teacher Education College, Zhejiang Normal University, China \\ ${ }^{2}$ Science Education Department, Faculty of Education Adekunle Ajasin University Akungba Akoko, Ondo State, \\ Nigeria
}

\begin{abstract}
The role of Critical thinking skill in developing 21st-century teaching profession can't be overstated. Projecting into the future, critical thinking is expected to serve as tools for integrating Artificial Intelligence into the teaching profession as well as an antidote to the threats of artificial intelligence to the teaching profession in the machine learning age. This study investigates John Dewey's philosophy on critical thinking and reviews existing literature on teaching profession. The questions raised by this study include: what is critical thinking requirement skill in 21st century? Does critical thinking serve as a means of integrating artificial intelligence (AI) into the teaching profession? What is the basic critical thinking skill and strategies needed for effective teaching that serve as an antidote to AI threats? The results imply that teachers need to acquire critical skills in order to outsmart machine, which has become a threat to many professions including teaching. The relevant teacher is one that does not function like a programmed machine. Ability to think critically is the answer to the "Austria vision 2030" (Machine learning age), teachers need to think critically in the teaching profession innovation as a major means to overcome AI threat and in order to be relevant in 21 st century machine learning age.
\end{abstract}

Keywords: Critical Thinking; Artificial Intelligence; Education; Antidote; Teaching; Profession

\section{Introduction}

The role of Critical thinking skill in developing 21st-century teaching profession can't be overstated. Teaching profession has originated from the social, economical, scientific and technological dimensions changes (Hotaman, 2010). Teacher education as a sector in teaching profession as play important role that need to be develop to measure up what is invoke in the 21 st century.

However, projecting into the future, critical thinking is expected to serve as tools for integrating Artificial Intelligence (AI) into the teaching profession as well as an antidote to the threats of artificial intelligence to the teaching profession in the machine learning age. AI being discussed at international venue such as UNESCO, Austrian council, United Union, Organization for Economic Cooperation and Development (OECD, 2019). UNESCO (2019) defines AI as sustainable development, which must be ensured that AI principles and its framework are human-centered. United Nation (2019) emphasized that AI is growing exponentially but is already coming closer to the benchmark of exceeding human capabilities by putting threat on job opportunities. Austria plays a major roles when it comes to digitalization with the highest real Gross Domestic Product (GDP) growth rate since 2011(Country Report, 2019). Austria 2030 mission on AI raised questions on challenges posed by the use of AI and robotics on changes and new demand at work (Austrian Council on Robotics and Artificial Intelligence, 2020).

Meanwhile, with the threat posed by AI on various sector and seen artificial intelligence quietly entering into the classroom (Wayne et al., 2019) it's suggest innovation in practice. The innovation in practice as suggested by this study in teacher education, examine critical thinking as tools for integrating Artificial Intelligence into the teaching profession. Huang (2019) described critical thinking as an emergence philosophical topic, was inspired by pragmatic philosopher John Dewey in 1910 and endorsed by analytic philosopher Max Black in 1946 (Robert, 2015, p 31). 


\section{Purpose of the Study}

In this article we summarize John Dewey's philosophy on critical thinking and reviews existing literature on teaching profession. The questions raised by this study include: what is critical thinking requirement skill in $21 \mathrm{st}$ century? Does critical thinking serve as a means of integrating artificial intelligence (AI) into the teaching profession? What is the basic critical thinking skill and strategies needed for effective teaching that serve as an antidote to AI threats?

\section{Methods}

The study adopted documents analysis qualitative research method. Document analysis is a systematic procedure for reviewing or evaluating documents, both printed and electronic computer-based and internettransmitted materials (Bowen, 2009). To provide answer to the three research questions raised by this study, John Dewey's books entitled 'How we think \& Democracy and education' and book chapters in 'Hand book on Research on Critical thinking and Teacher Education Pedagogy' and reviews existing literature in teaching profession on critical thinking. Theoretical perspective view of John Dewey was used as the bases of assumption and that was subjected to critique by review of related literatures on critical thinking.

\section{Theoretical perspective}

The critical thinking also refer to reflective thinking (Letseka \& Zireva, 2013) and its related to education can be traced back to John Dewey's books entitled How we think \& Democracy and education (John Dewey, 1933, 2001). Inside "How we think" book, phases of reflective thinking consist of two categories: a state of doubt and an act of searching, hunting and inquiring (John Dewey, 1933, p.12). While inside "Democracy and education" book Chapter 12, identify 'thinking' as method of intelligent learning and educative experience that employs and rewards mind. In this book, thinking as an essential method of reflection (critical) consists of five categories: experience, stimulus to thought, possesses information, suggested solution, application.

John Dewey philosophy on critical thinking that was once neglected, has now been bedrock and widely use by the researcher to address the $21^{\text {st }}$ century classroom challenges (Williams, 2017). He believed that, 'thinking is the method of intelligent learning and that it is employ to rewards mind'. In $21^{\text {st }}$ century whereby AI principle is design and structured to be human-centered (UN, 2019), human need to exhibit a unique trait that is unavailable in machine. In table 1, this illustrated intra-relationship of critical skill and their strategies indicators within teaching profession.

John Dewey, he of the opinion that situation of thinking can only occur in the process of doubt and which gives chances for searching or inquiring (Letseka \& Zireva, 2013). Our view is that, teachers need to develop ability to think. Exploring (John Dewey, 2001, p. 158) he explained that initial stage of developing experience as 'thinking' which induce learning. As he further explained that teacher need some materials to stimulate student thinking and challenge thought to solve new problem. (John Dewey, 2001, p.163) Stated the required 'data' needed in critical thinking 'memory, observation, reading and communication', of which if accurately developed by teacher and know how to use it interchangeable can make then outsmart machine. The 'data arouse suggestions'(John Dewey, 2001, p. 164), teachers will be able to gives possible solution to the problem at hand. Application is use to test the idea emanated from thought, that is why John Dewey discourage recitation which can only make suggested half-understanding and ill-digested material (John Dewey, 2001, p. 167). Meanwhile a recent published editorial article (Šorgo, 2020) even suggested that the best way to leave battle to the intelligent machines in teaching profession is that teacher should just serve as observer. 


\section{Related literatures}

\section{Critical thinking requirement skill in $21^{\text {st }}$ century}

Teaching profession is facing new kinds of responsibilities, roles and competences in the 21st century (Voinea \& Pălăşan, 2014). As technology has been seen advancing in quantity and quality; recognized as a requirement of 21st century learners and students' perspectives were positive toward the inclusion of technology-enhanced learning, and use in supporting their development of critical thinking (Swart, 2017). Similarly, (Ab Kadir, 2017) study on what teacher knowledge matters in effectively developing critical thinker in the $21^{\text {st }}$ century curriculum, and found that teacher knowledge domain must be equipped, whereby a revised framework of teacher knowledge was proposed that will include heuristic and analytical tools. Communication skill is also one of vital requirement skill for critical thinking that can be greatly influenced by sociocultural influences in the classroom. Exploring through critical thinking, questioning and student engagement in Korean university English courses revealed that cultural and institutional factors, as well as limitations in English language proficiency, can impact participation in student-centered, critical thinking activities (DeWaelsche, 2015).

\section{Critical thinking as a means of integrating artificial intelligence (AI) into the teaching profession}

'AI offers this same transformative potential for the augmentation and potential replacement of human tasks and activities within a wide range of industrial, intellectual and social applications' (Dwivedi et al., 2019)

The augment launches AI into new era, (Dwivedi et al., 2019) opinion paper is a combination of multidisciplinary perspectives of AI comprises of 35 expert from different field which discuss extensively on emerging challenges, opportunities, and agenda for research, practice and policy. It was found that humans activities on AI processing are likely to focus more on adding value on design, analysis and interpretation based on AI processing and outputs, and can be used in wide range of industrial, intellectual and social application. As this study stands to look into the intellectual (critical thinking) aspect. In teaching profession, Artificial intelligence (AI) is now enhancing tools and instruments used day by day in cities and campuses around the world. Teaching in higher education requires a reconsideration of teachers' role and pedagogies (Popenici \& Kerr, 2017). There is need to look into the teacher' role and pedagogies, using critical thinking by the teaching as a mean to be relevance in the age of machine (AI) is very crucial in teaching profession. As we know that machine cannot think is garbage in garbage out, any type of machine can only work with available information in their database and AI cannot independently "develop new context and learn like humans," they are inherently "human-dependent" (Su, 2017). It was later concluded by Su (2017) that, AI should be developed in other to answer 'why humans do thing'.

\section{Basic critical thinking skill and strategies needed for effective teaching}

As AI shown to be treat for this $21^{\text {st }}$ century, Saputri et al. (2019) study identify critical thinking skill as one of the important skills that can deal with the arising demand and challenges in $21^{\text {st }}$ century. According to Martin and Ronald (2015) study categories the critical thinking skills into; lower level, higher level, complex level and thinking about thinking level. Saputri et al. used Stimulating Higher-Order-Thinking Skills (Stim-HOTs) model with six indicators; interpretation, analysis, evaluation, conclusion, explanation, and self-regulation as innovative model to train students' critical thinking skill, which form one the key component of John Dewey philosophy 'Stimulus to thought'. Also, a book chapter in 'Hand book on Research on Critical thinking and Teacher Education Pedagogy' Knight \& Robinson (2019) emphasized on international mandate for critical thinking to serve a vital 21st century skill (Machine learning age) in teacher education. In chapter 6, Foster and Fleenor (2019) had shown another indicator 'Constructs- problem posing and dialogue' which can serve as 
strategies to enhance critical thinking and reflection amongst teachers, this study is still pinpointing John Dewey philosophy 'reflective thinking'. Among other strategies as suggested by researchers in the hand book were; Model to train pre-service science teachers, adopting self-assessment in English teachers, project approach in early childhood education, dialogic model-argumentative activities in the classroom (Burks\& Huffman, 2019; Boyd, 2019; Jordan et al. 2019; Orakc1 et al. 2019).

Table 1; Intra-relationship of critical skill and their strategies indicators

\begin{tabular}{lcl}
\hline Authors & \multicolumn{1}{c}{ Indicators } & field covered \\
\hline John Dewey, (1933) & $\begin{array}{c}\text { Doubt, } \\
\text { Act of searching, hunting } \\
\text { inquiring }\end{array}$ & Philosophy \\
John Dewey, (2001) & $\begin{array}{c}\text { experience, stimulus to thought, } \\
\text { possesses information, } \\
\text { Suggested solution, application. }\end{array}$ & \\
Saputri et al.(2019) & $\begin{array}{c}\text { model; interpretation, analysis, } \\
\text { evaluation, conclusion, explanation, } \\
\text { and self-regulation }\end{array}$ & Students training \\
Knight \& Robinson (2019) & $\begin{array}{c}\text { International mandate } \\
\text { Foster \& Fleenor, (2019) }\end{array}$ & Constructs- problem posing \\
and dialogue & Teacher education \\
Burks\& Huffman, 2019 & Model & Teacher training \\
Orakc1 et al. 2019 & Self-assessment & $\begin{array}{l}\text { Pre-service science } \\
\text { teachers }\end{array}$ \\
Jordan et al. 2019 & Project approach & English teacher \\
Boyd, 2019 & Dialogic model-argumentative & $\begin{array}{l}\text { education } \\
\text { Classroom activities } \\
\text { Activities }\end{array}$ \\
\hline
\end{tabular}

\section{Discussion}

In this study, we have summarized John Dewey's philosophy on critical thinking and reviews existing literature on teaching profession. It was shown that teachers need to acquire critical thinking skills in order to outsmart machine, which has become a threat to many professions including teaching. From the theoretical perspective, as shown that the stone that the builder rejected has now become the corner stone, key findings on escape root out of the AI threat on teaching profession as suggested by today researchers was based on John Dewey's philosophy on critical thinking. Teacher need to possess ability to reflect on thought, that will give room to aorta of doubt which can lead to searching or inquiring for better understanding. However, the role plays by the robot still lack some characteristics like intellect which make human to outsmart machine ( $\mathrm{Su}$, 2017). This shortcoming of AI can lead to misjudge/ misrepresentation because whatever that is inputted into machine is what it bring out (garbage in garbage out). For example, if an AI machine is programmed to classify between right and wrong answer, if the wrong answer is inputted as the right one the machine output the wrong answer as the correct one and vice versa.

Also, in teaching profession critical thinking skills used in the area of student training, teacher educator, training of pre-service teachers' and classroom activities in this 21 st century as shown to serve as an antidote to AI threats. In teaching profession Artificial intelligence (AI) can only as serve enhancing tools or instruments, which cannot replace the human knowledge, teachers only need to activate their thinking domain to overcome 
AI threat and in order to be relevant in 21st century machine learning age and to further answer the questions raised by Austria 2030 mission on challenges posed by the use of AI and robotics on changes and new demand. Innovation in practice in teaching profession needs reconsideration of teachers' role and pedagogies as there is new demand at work (Popenici \& Kerr, 2017), teachers should activate their thinking domain and they should not be an observer, as recent studies as shown that AI is already in the classroom (Šorgo, 2020; Wayne Holmes et al., 2019).

\section{Conclusions and implications}

Consequentially, important conclusions can be infer from the findings on how critical thinking as a 21 st century skills can be used to integrate AI into teaching profession that serve as an antidote to AI threats. The relevant teacher is one that does not function like a programmed machine. Ability to think critically is the answer to the “Austria vision 2030"( Machine learning age), teachers need to think critically in the teaching profession innovation as a major means to overcome AI threat and in order to be relevant in this 21 st century machine learning age. Moreover, further research could combine John Dewey perspective on critical thinking and qualitative analyses research.

\section{Acknowledgements}

The authors acknowledged the funding of Chinese Government Scholarship (CSC No: 2018GXZ020090), and also appreciate the management of Zhejiang Normal University, Jinhua. Zhejiang Province, China.

\section{References}

Austrian Council on robotics and artificial intelligence (2020). FAQ "Robotics and AI technologies must be aligned with human needs." https://www.acrai.at/en/information/faq/

Ab Kadir, M. A. (2017). What teacher knowledge matters in effectively developing critical thinkers in the $21 \mathrm{st}$ century curriculum? Thinking Skills and Creativity, 23, 79-90.

Bowen, G. A. (2009). Document analysis as a qualitative research method. Qualitative Research Journal, 9(2), 27-40.

Country Report. (2019). Monitoring progress in national initiatives Country report. WIK Consult.

DeWaelsche, S. A. (2015). Critical thinking, questioning and student engagement in Korean university English courses. Linguistics and Education, 32, 131-147.

Dwivedi, Y. K., Hughes, L., Ismagilova, E., Aarts, G., Coombs, C., Crick, T., Williams, M. D. (2019). Artificial Intelligence (AI): Multidisciplinary perspectives on emerging challenges, opportunities, and agenda for research, practice and policy. International Journal of Information Management, 1-47

Hotaman, D. (2010). The teaching profession: Knowledge of subject matter, teaching skills and personality traits. Procedia - Social and Behavioral Sciences, 2(2), 1416-1420.

Huang, Y. (2019). Establishing critical thinking course for high school students in China: A Literature review in pedagogy field. Proceeding of the 5th International Conference on Education, 5, 59-66.

John Dewey. (1933). How we think a restatement of the relation of reflective thinking to the educative process. HEATH AND COMPANY Lexington, Massachusetts.

John Dewey. (2001). Democracy and Education. In A Penn State Electronic Classics Series Publication, 16.

Letseka, M., \& Zireva, D. (2013). Thinking: Lessons from John Dewey’s How We Think. Academic Journal of Interdisciplinary Studies, 2(2), 1-11.

Martin Davies \& Ronald Barnett. (2015). The Palgrave Handbook of Critical Thinking in Higher Education. Palgrave Macmillan.

Nation United. (2019). United Nations Activities on Artificial Intelligence (AI).

Popenici Stefan \& Kerr Sharon. (2017). Exploring the impact of artificial intelligence on teaching and learning in higher education. Research and Practice in Technology Enhanced Learning, 12(22), 1-13. 
Robert H, E. (2015). Critical Thinking: A Streamlined Conception. In: Davies M., Barnett R. (eds) The Palgrave Handbook of Critical Thinking in Higher Education.

Saputri, A. C., Sajidan, Rinanto, Y., Afandi, \& Prasetyanti, N. M. (2019). Improving students' critical thinking skills in cell-metabolism learning using Stimulating Higher Order Thinking Skills model. International Journal of Instruction, 12(1), 327-342.

Šorgo, A. (2020). The teacher's role in the battle of the intelligent machines. Journal of Baltic Science Education, 19(1), 4-5.

Swart, R. (2017). Critical thinking instruction and technology enhanced learning from the student perspective: A mixed methods research study. Nurse Education in Practice, 23, 30-39.

UNESCO. (2019). Artificial Intelligence for Sustainable Development Programme. UNESCO. https://en.unesco.org/sites/default/files/mlw2019-programme.pdf

Voinea, M., \& Pălăşan, T. (2014). Teachers' Professional Identity in the 21st Century Romania. Procedia Social and Behavioral Sciences, 128, 361-365.

Wayne Holmes, Maya Bialik, \& Fadel Charles. (2019). Artificial Intelligence In Education: Promises and Implications for Teaching. The Center for Curriculum Redesign

Williams, M. K. (2017). John Dewey in the 21 st Century. 9(1), 91-102. 